\title{
RANCANG BANGUN SISTEM MONITORING PERKEMBANGAN ANAK DI TKIT TAAMASA MEGGUNAKAN METODE SPIRAL
}

\author{
Yudi Mulyanto $^{1}$, Yana Karisma ${ }^{2}$, Umara Maharani ${ }^{3}$ \\ 1,2,3), Program Studi Informatika, Universitas Teknologi Sumbawa \\ Email: yudi.mulyanto@uts.ac.id
}

\begin{abstract}
Abstrak: Penelitian ini bertujuan untuk merancang dan membangun sistem monitoring perkembangan anak di TK IT TAAMASA. Adapun metode perangkat lunak yang digunakan yaitu dengan menggunakan metode spiral. Sistem ini dibangun menggunakan pemrograman PHP dengan menggunakan CSS, Bootsrap dan MySql sebagai database. Adapun metode pengumpulan data yang digunakan dalam penelitian ini yaitu observasi, wawancara, dan studi pustaka serta menggunakan metode spiral sebagai metode pengembangan perangkat lunak. Adapun metode pengujian yang dilakukan dengan melalui pengujian black-box yaitu pengujian yang dilakukan dengan menguji perangkat lunak dari segi fungsionalitas. Hasil dari penelitian ini yaitu aplikasi sistem monitoring perkembangan anak di TK IT TAAMASA agar dapat memberi informasi perkembangan anak dengan mudah kepada orang tua saat ini yang masih dilakukan secara manual.
\end{abstract}

Kata Kunci: TK IT TAAMASA, Black Boxt, Spiral

\begin{abstract}
This research aims to design and build children's monitoring development system IT TAAMASA kindergarten the aims this research is build children's development monitoring system using spiral method to provide information on children's development at IT TAAMASA kindergarte. Futhermore this research is used spiral as be method to develop the software. So, the software makes parents easier to get information regarding their child cognitive development. The system is build by using PHP programming, CSS, Bootstrap and MYSQL as databases. The methods of data collection used in this study are observations, interviews, and library studies. The testing method is done by going through the black-box testing.
\end{abstract}

Keywords: TK IT TAAMASA, Black Boxt, Spiral

\section{PENDAHULUAN}

Perkembangan teknologi memiliki peran penting dalam kehidupan manusia, salah satunya perkembangan teknologi informasi. Saat ini sistem informasi sudah menjadi sarana komunikasi yang penting dan efektif diseluruh dunia dan banyak bidang menggunakannya. Seperti halnya dalam bidang pendidikan dan dalam bidang kemasyarakatan telah banyak diimplementasikan dan terbukti memberi manfaat untuk masyarakat. Bidang pendidikan pun kini sudah mulai menggunakan teknolog informasi dalam proses pembelajaran disekolah.

Penulis akan membahas masalah pendidikan menjadiobjek penelitian yang bertempat pada TK IT TAAMASA di Villa Matahari Dusun Karang Padak Labuan Sumbawa. Alasan penulis melakukan penelitian di TK ini karena propersi antara guru dan murid lebih ideal (1:15) yang memberikan dampak positif terhadap kegiatan pembelajaran karena monitoring dapat dilakukan secara lebih terukur. Meski demikian informasi tentang anak masih hanya terjadi dalam satu jalur komunikasi (antara siswa dan guru) dan tidak dapat melakomodir hubungan antara guru dan orang tua murid secara real time. Akibatnya orang tua murid hanya mendapatkan informasi mengenai putra-putrinya, dalam jangka waktu yang cukup lama, sehingga jika suatu waktu terjadi penurunan kemampuan siswa atau masalah-masalah teknis lainnya orang tua murid tidak dapat mengambil suatu tindakan secara langsung, ditambah lagi pada rentan usia ini anak-anak masih sangat membutuhkan perhatian dari orang tua dan para guru. Maka penulis berusaha memberikan suatu upaya solutif untuk memecahkan masalah diatas dengan membuat sistem monitoring perkembangan anak secara online. Dengan sistem ini dapat mempermudah orang tua dan guru dalam melakukan pengawasan perkembangan belajar anak. Sehingga orang tua bisa melakukan proses monitoring perkembangan anak di sekolah.

\section{TINJUAN PUSTAKA}

Dalam suatu penelitian diperlukan dukungan hasil-hasil penelitian yang telah ada sebelumnya yang berkaitan dengan penelitian tersebut. Dalam penelitian ini penulis memberikan dua refrensi terdahulu yaitu : Dari penelitian Surina, membuat sebuah aplikasi yaitu "Aplikasi Deteksi Dini Tumbuh Kembang Anak Usia Nol Hingga Enam Tahun Berbasis Android" dibuat dengan menerapkan metode pengembangan protype untuk mempermudah peneliti ketika membuat aplikasi tersebut. Didalam jurnal tersebut juga dijelaskan bahwa aplikasi tersebut didedikasikan untuk anak usia $0-6$ tahun dan di tujukan untuk orang tua serta tim medis kesehatan yang bertugas di puskesmas guna memberikan informasi mengenai tumbuh kembang anak dengan pemanfaatan pemanfaatan teknologi web dan android dengan menggunakan android studio [3]. Sedangkan sistem yang dibuat oleh penulis yaitu sistem monitoring perkembangan anak yang berjenis hybrid. Adapun perbedaan yang dimiliki dalam aplikasi tersebut ialah menggunakan metode pengembangan perangkat lunak yakni spiral karna metode ini merupakan proses pengembangan perangkat lunak evolusionar yang menggabungkan pendekatan prototyping yang bersifat iterative dengan 
aspek-aspek sistematis dan terkendali seperti yang kita jumpai pada waterfall. Jadi kelebihan dari aplikasi yang dibuat oleh penulis lebih mudah dipahamioleh user dan tampilannya menarik.

\section{Rancang Bangun}

Pada bagian ini, penulis menjelaskan tentang definisi rancang bangun menurut Jogiyanto pengertian Rancang Bangun (desain) yaitu tahap setelah analisis dari siklus pengembangan sistem yang merupakan pendefinisian dari kebutuhan fungsional, serta menggambarkan bagaimana suatu sistem dibentuk yang dapat berupa penggambaran, perencanaan dan pembuatan sketsa atau pengaturan dari beberapa elemen yang terpisah ke dalam satu kesatuan yang utuh dan berfungsi, termasuk menyangkut mengkonfigurasikan dari komponen- komponen perangkat keras dan perangkat lunak dari suatu sistem[2].

\section{Sistem}

Penulis menjelaskan definisi sistem menurut Al-Fatta, secara umum sistem dapat didefinisikan sebagai suatu jaringan kerja dari prosedur-prosedur yang saling berhubungan atau berkumpul bersamasama untuk melakukan suatu kegiatan atau untuk melakukan sasaran tertentu[1].

\section{METODOLOGI}

Metode yang digunakan dalam penelitian ini adalah penelitian deskriptif kualitatif yang dimana menurut Moleong deskriptif kualitatif artinya mencatat dengan teliti berbagai fenomena yang dilihat dan didengar serta dibaca via wawancara atau catatan lapangan, foto, video tape, dokumentasi pribadi, catatan serta memo dan lain-lain. Peneliti harus membanding-bandingkan, mengkombinasikan, mengabstraksikan dan menarik kesimpulan [4]. Dalam penelitian deskriptif kualitatif jenis data yang dikumpulkan berupa kata-kata, gambar dan bukan angka-angka. Hal ini dikarenakan berbagai data yang terkumpul kemungkinan menjadi kunci terhadap apa yang akan atau sudah diteliti.

Metode pengembangan perangkat lunak yang digunakan dalam penelitian skripsi "Rancang Bangun Sistem Monitoring Perkembangan Anak TK IT TAAMASA Menggunakan metode spiral, karena model proses pengembangan perangkat lunak spira Menurut Pressman dalam Wanita, model spiral merupakan model proses pengembangan perangkat lunak evolusioner yang menggabungkan pendekatan prototyping yang bersifat iteratif dengan aspek-aspek sistematis dan terkendali seperti yang kita jumpai pada model air terjun (waterfall)[5].

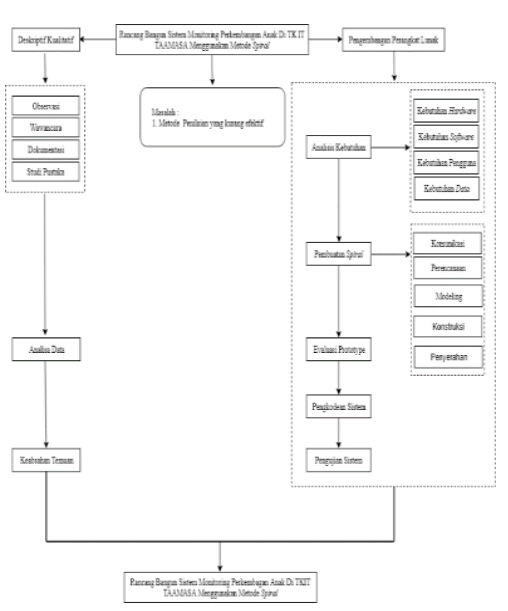

Gambar 1. Alur Penelitian

\section{HASIL DAN PEMBAHASAN}

Hasil Pengumpulan Data

Adapun penerapan dari hasil metode pengembangan prangkat lunak Spiral yang telah diterapkan sampai dengan penyerahan pada penelitian ini dibagi atas pembahasan hasil pengumpulan data, perancangan sistem dan pembangunan sistem monitoringperkembangan anak di TK TAAMASA yang telah dilakukan.

\section{Wawancara}

Pada tahap wawancara dilakukan dengan wawancara langsung. Metode wawancara langsung dilakukan dengan memberikan pertanyaan langsung kepada guru TK IT TAAMASA dari proses wawancara yang dilakukan bahwa pihak sekolah mendukung dalam pembuatan sistem monitoring perkembangan anak di TK IT TAAMASA.

Observasi

Setelah melakukan observasi di TK IT TAAMASA, sekolah tersebut bersedia memberikan data berupa dokumen rekapan penilaian di TK IT TAAMASA untuk sistem monitoring yang akan dibangun.

Dokumentasi

Pada tahap ini peneliti melakukan dokumentasi dengan cara mengambil gambar berkas rekapan penilaian yang tertera pada lampiran.

Pengembangan Perangkat Lunak 
Model yang digunakan pada skripsi ini merupakan model spiral, dalam pengembangan aplikasi monitoring TK IT TAAMASA peneliti menggunakan metode spiral dengan melakukan 5 langkah diantaranya yaitu sebagai berikut:

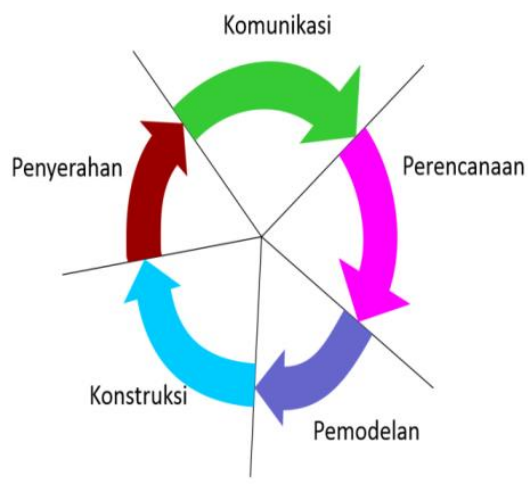

Gambar 2. Metode Spiral

Komunikasi

Tahapan ini merupakan bagian dari pendekatan peneliti tehadap salah satu guru di TK IT TAAMASA untuk mengetahui sistem apa yang selama ini digunakan di TK TAAMASA bahwa sekolah tersebut belum memiliki sistem monitoring perkembangan anak guna untuk melihat kemajuan anak di TK IT TAAMASA sehingga dari hasil komunikasi beberapa kali bahwa peneliti mendapat gambaran dari sistem yang akan dirancang sesuai dari kondisi permasalahan yang dihadapi dan keingin yang diinginkan dalam kemajuan sekolah TK IT TAAMASA.

\section{Perencanaan}

Pada tahap kedua ini dilakukan perancanaan terhadap hasil dari tahap awal komunikasi sehingga peneliti membuat proses jadwal pengerjaan untuk membangun aplikasi monitoring perkembangan anak pada TK IT TAAMASA, sehingga perencanaan inilah yang nantinya sebagai rujukan dalam pembangunan aplikasi dan kebutuhan-kebutuhan dalam mendukung pembangunan aplikasi ini, dibawah ini dapat dilihat jadwal pengerjaan aplikasi selama 3 bulan dari bulan mei hingga bulan juli kemudian kebutuhan perangkat dalam membangun aplikasi monitoring perkembangan anak.

Tabel 1. Analisis Kebutuhan Perangkat Keras

\begin{tabular}{|c|c|c|}
\hline No & $\begin{array}{c}\text { Perangkat } \\
\text { Keras }\end{array}$ & Spesifikasi \\
\hline
\end{tabular}

\begin{tabular}{|c|c|c|}
\hline 1 & Laptop & \begin{tabular}{|ll} 
a. & $\begin{array}{l}\text { Processor intel } \\
\text { core } \mathrm{i} 3 \text { 2348M }\end{array}$ \\
b. & Intel HD \\
& Graphics \\
c. & 14.0 HD LED \\
& LCD \\
d. & RAM 2 GB \\
& DDR 3 \\
e. & Harddisk 500 \\
& GB \\
\end{tabular} \\
\hline 2 & Smartphone & $\begin{array}{ll}\text { a. } & \text { CPU Octa-core } \\
& 1,5 \mathrm{GHz} \\
\text { b. } & \text { RAM } 2 \mathrm{~GB} \\
\text { c. } & \text { Intel memory } 32 \\
& \text { GB } \\
\text { d. } & \text { Android versi } \\
& 4.4 \text { Kitkat }\end{array}$ \\
\hline
\end{tabular}

Analisis Kebutuhan Perangkat Lunak

Beberapa perangkat lunak yang dibutuhkan dalam membangun sistem monitoringperkembangan anak TKIT TAAMASA.

Tabel 2. Analisis Kebutuhan Perangkat Lunak

\begin{tabular}{|c|l|c|}
\hline No & \multicolumn{1}{|c|}{ Perangkat Lunak } & Versi \\
\hline 1 & Visual Studio Code & 1.36 .1 \\
\hline 2 & Windows & 7 Ultimate \\
\hline 3 & XAMPP & 3.2 .2 \\
\hline 4 & PhpMyAdmin & 4.8 .0 \\
\hline 5 & MySQL & 5.0 .12 \\
\hline 6 & $\begin{array}{l}\text { Browser Google } \\
\text { Chrome }\end{array}$ & 66.0 .3359 .181 \\
\hline
\end{tabular}

a.Rancang Sistem

Dalam rancang sistem monitoring perkembangan anak di TK IT TAAMASA menggunakan metode spiral ini terdiri 4 jenis diagram sebagai berikut:

\section{Usecase Diagram}

Usecase Diagram dari sistem monitoring perkembangan anak di TK IT TAAMASA sebagai berikut :

\section{Use Case Diagram Untuk Admin}

Berikut ini merupakan usecase diagram untuk bagian admin, yang menjelaskan ubungan sistem 
dengan aktifitas-aktifitas pada prosedur perkembangan monitoring anak.

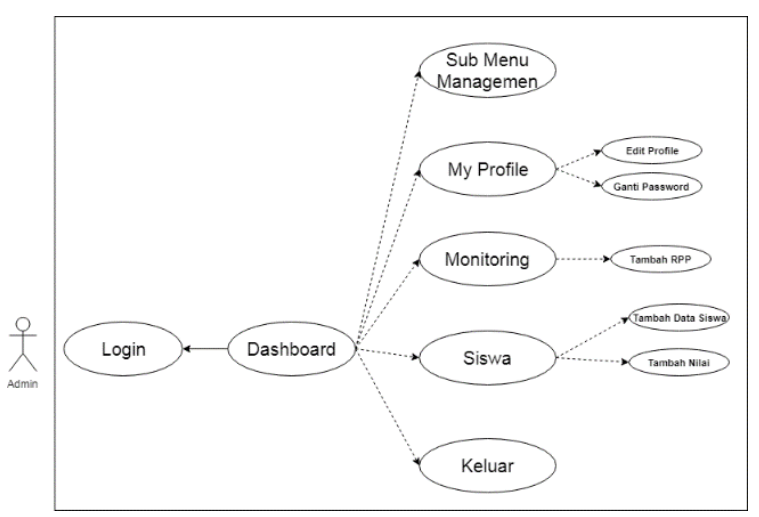

Gambar 3. Use Case Diagram untuk Admin

Pada gambar di atas dapat dijelaskan bahwa terdapat seorang admin yang berada di luar sistem, yang dimana terdapat halaman login yang harus dilalui kepada seorang admin, kemudian dalam pengaksesan fungsi admin dapat melakukan pengisian data maupun update data yang terdiri dari menu siswa, monitoring, my profile, dan sub menu. Berikut adalah tabel yang akan di jelaskan secara detail :

\section{Usecase Diagram User}

Berikut ini adalah merupakan usecase diagram untuk bagian user yang menjelaskan hubungan system dengan aktifitas-aktifitas pada system informasi

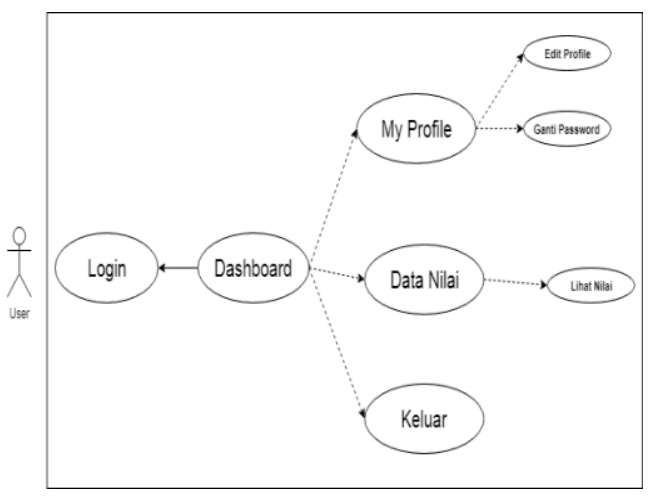

Gambar 4. Use Case Diagram untuk Admin

\section{Activity Diagram}

Activity diagram menjelaskan aktivitas-aktivitas yang terjadi dalam system monitoring perkembangan anak. Pada activity diagram dibagi menjadi dua bagian yaitu bagian admin dan user atau anggota system monitoring perkembangan anak yang merupakan diagram yang menjelaskan interaksi antara system dengan system di dalam informasi yang dibangun.
Activity Diagram Admin Login

Gambar berikut berikut ini adalah gambar activity diagram saat admin ingin membuka menu login pada system.

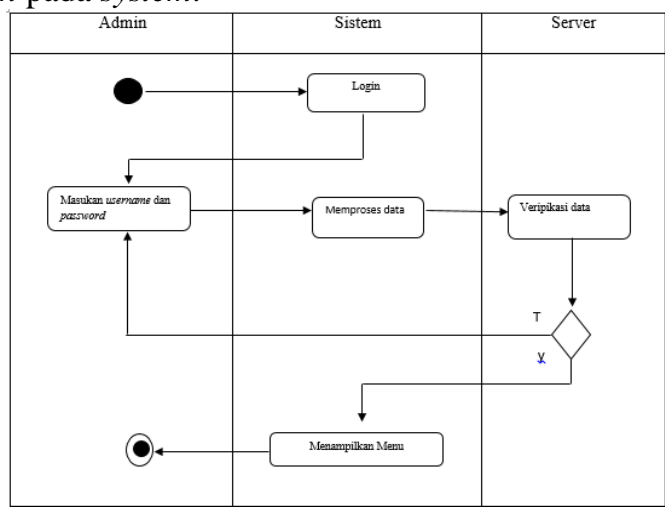

Gambar 5. Activity Diagram login Admin

Proses dimulai yaitu pada saat admin membuka tampilan masuk atau login maka sistem akan menampilkan tampilan masuk untuk admin lalu admin dapat memasukkan username dan password untuk akun admin. Selanjutnya dilakukan pengecekan validasi data yang dimasukkan jika benar maka sistemakan menampilkan panel admin.

Activity Diagram untuk bagian monitoring

Gambar berikut berikut ini adalah gambar activity diagram saat admin inginmembuka menu monitoring padaSystem .

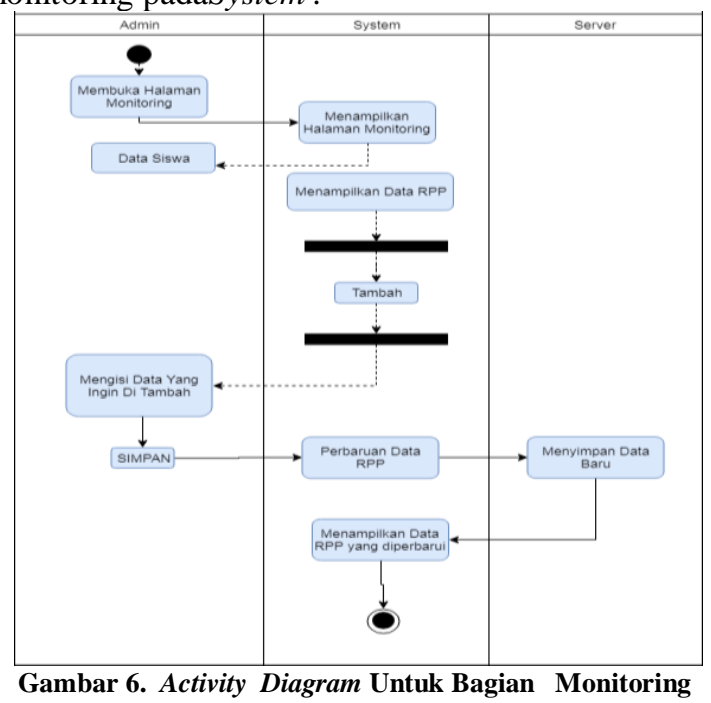

Pada halaman Monitoring dapat menampilkan namanama siswa disini admin dapat menambah data RPP yang akan di input pada menu monitoring. Untuk menambah data RPP systemakan menampilkan form tambah data RPP kemudian admindapat mengisi form sesuai dengan data RPP yang ingin ditambah. 


\section{Squencial Diagram}

Squencial diagram menjelaskanpermodelan system yang akan dibangun untuk menunjukan intraksi antara objek yang disusun berdasarkan urutan waktu dan merupakan tahap proses dari use case diagram yang telah dibuat.

1) Squencial Diagram untuk bagian admin

2) Squencial Diagram login

Gambar berikutini adalah gambar squencial diagram saat admin msuk ke dalam system.

Proses dimulai yaitu pada saat admin membuka tampilan masuk atau login maka sistem akan menampilkan tampilan masuk untuk admin lalu admin dapat memasukkan username dan password untuk akun admin. Selanjutnya dilakukan pengecekan validasi data yang dimasukkan jika benar maka sistem akan menampilkan panel admin.

3) Squencial Diagram untuk bagian RPPM

Gambar berikut ini adalah gambar squencial diagram saat admin msuk ke dalam menu RPPM.

Pada halaman RPPM dapat menampilkan subsub menu disini admin dapat menambah, data RPPM data RPPM yang berisikan data siswa yang nantinya akan di olah oleh admin, dan dapat dilihat pada gambar diatas bahwa admin harus terlebih dahulu login kemudian kemudian memilih menu utama disini admin hanya memilih menu monitoring dengan melakukan interaksi pengimputan data.

4) Squence Diagram Data Siswa

Gambar berikut ini adalah gambar squence diagram saat admin msuk ke dalam menu Data Siswa.

Pada halaman data siswa dapat menampilkan sub-sub menu disini admin dapat menambah data siswa yang akan di input pada button data siswa. Untuk menambah data siswa sistem akan menampilkan form tambah data siswa kemudian admindapat mengisi form sesuai dengan data diri dan nilai siswa yang ingin ditambah.

5) Squence Diagram untuk bagian Pengguna/ User a. Squence Diagram Login

Gambar berikut ini menjelaskan squencial diagram menampilkan proses login oleh user.

Proses dimulai yaitu pada saat user membuka tampilan masuk atau login maka sistem akan menampilkan tampilan masuk untuk user lalu user dapat memasukkan username dan password untuk akun user. Selanjutnya dilakukan pengecekan validasi data yang dimasukkan jika benar maka sistemakan menampilkan panel user dan di tunjukan dengan menu utama user.

b. Squence Diagram Untuk Data Siswa
Gambar berikut berikut ini adalah gambar squence diagram saat user ingin membuka menu data nilai pada sistem.

Proses dimulai yaitu padasaat user membuka menu monitoring maka sistem akan menampilkan halaman monitoring. User dapat melihat data-data nilai yang terdiri dari data nilai harian, mingguan,bulanan dan koleksi gambar.

\section{c. Class Diagram}

Pada class diagram mendiskripsikan jenis-jenis objek dalam sitem dan berbagai macam hubungan statis yang terjadi pada sistem monitoring perkembangan anak. Class Diagram juga menunjukkan property dan operasi sebuah class dan batasan yang terdapat dalam hubungan dengan objek.

\section{KESIMPULAN SARAN}

Berdasarkan hasil dari analisis dan perancangan sistem yang telah dilakukan. Adapun kesimpulan yang dapat ditarik oleh penulis dari proses penelitian ini yaitu:

\section{Kesimpulan}

1. Rancang Bangun Sistem Monitoring Perkembangan Anak Di TK IT TAAMASA Menggunakan Metode Spiral telah selesai dibangun dengan menggunakan bahasa pemrograman PHP dan database MySQL. Metode pengembangan yang digunakan yaitu metode yaitu metode perancangan terstruktur yang meliputi Usecase, Activity Diagram,Squecial Diagram.dan Class Diagram dan perancangan tampilan interface menggunakan microsoft office visio 2007.

2. Menghasilkan sistem informasi yang dapat diakses oleh orang tua sehingga orang tua bisa melihat informasi mengenai nilai-nilai anak disekolah TK IT TAAMASA.

3. Selanjutnya dari segi admin dapat mengolah data apa saja yang harus diinput pada web dengan proses edit, tambah, dan hapus data.

\section{Saran}

Dari hasil pembuatan sistem monitoring perkembangan anak di TK IT TAAMASA menggunakan metode spiral, adapun saran yang dapat penulis sampaikan untuk pengembangan selanjutnya agar menjadi lebih baik,yaitu :

1. Kedepannya tampilan interface dapat dibuat menjadi menarik. 
2. Kedepannya dapat ditambahkan menu cetak untuk user sehingga nilainya dapat dicetak oleh user.

3. Diharapkan kedepannya ruang lingkup dapat digunakan oleh semua kelas di TK IT TAAMASA.

\section{DAFTAR PUSTAKA}

[1] Al-Fatta Hanif.2007. Analisis dan Perancangan Sistem Informasi. Yogyakarta: Penerbit Andi.

[2] Andry, J. F.2016. Sistem Informasi Monitoring Proyek Furniture Di Pt. Xyz. STUDIA
INFORMATIKA. Vol 9 No 2.Tanggal akses 24 Juli 2019.

[3] Surina Nia. 2015. Aplikasi Deteksi Dini Tumbuh Kembang Usia Nol Hingga Enam Tahun Berbasis Android. Vol 7 No 1.Tanggal akses 05 Juli 2019.

[4] Moleong, M.A.2015.Metodologi Peelitian Kualitatif. Bandung: PT REMAJA ROSDAKARYA

[5] Wanita First, dkk. 2017. Rancang bangun sistem informasi Terpadu Makananan Pendanmping ASI Yang Bernilai Gizi Tinggi dan Berbahaya untuk Lokal. Vol 7 No 2.Tanggal Akses 18 Juli 2019. 